DOI 10.15826/QR.2016.1.148

УДК 76.021+769.91+351.751.5

\title{
SERGEY CHEKHONIN: THE SICKLE AND THE HAMMER OR THE MONSTER COCKROACH (TARAKANISHCHE) ${ }^{\star 1}$
}

\author{
Sergey Golynets \\ Ural Federal University, \\ Yekaterinburg, Russia
}

A number of Soviet artists were working in 1918 on the emblem of the RSFSR that became four years later the basis for the Soviet coat of arms. Sergey Vasilievich Chekhonin was the one who gave the coat of arms and the flag of the newlyborn Russian Federation their final form. The symbol, expressive and stripped of the macabre meaning of the reality behind it, found an impeccable composition and form by virtue of one of the most virtuous and talented Russian graphics. Chekhonin's artistic heritage has not been studied enough. The author of the article, based upon study of bibliographic rarities, illustrated and designed by Chekhonin, addresses the most important pages of the master's creative work, studying as well the publications of the late 1910s-1920s, and diaries of that time. Chekhonin's enthusiasm and keenness in cooperating with the new authority, and working on Soviet emblems, bewildered his fans. The article examines Chekhonin's attitude to contemporary events in the aspect of the topic "Mir iskusstva" and the Revolution. Members of Mir iskusstva community, having sympathetically met the overthrow of the autocracy, ever since the October Revolution were ready to take an active part in the work on the protection of architectural monuments and museum treasures, on improving artistic pedagogy, publishing and theater business. However, their enthusiasm soon gave way to a feeling of anxiety and frustration. In the mid-1920s, many of Mir iskusstva members found themselves abroad. Chekhonin was no exception. The artist developed critical and skeptical mood, most fully manifested in his illustrations to The Monster Cockroach, a famous fable in verse by Korney Chukovsky. Analyzing the text of The Cockroach and comparing it with other fables by Chukovsky, as well as with the diary entries of the writer, the author of the article argues that The Cockroach was not addressed exclusively to children. It is not by chance that the image of a 'monster cockroach' also appeared in the ominous poem by Osip Mandelstam (Tarakan'i smeyutsya glazishcha i sverkayut yego golenishcha... ("The Cockroach's eyes are laughing, and the shafts of his boots are shining...")); further on, in the famous play by Evgeny Shvarts, the Cockroach grew to the size of a giant dragon. Chekhonin undoubtedly

* Citation: Golynets, S. (2016). Sergey Chekhonin: The Sickle and The Hammer or The Monster Cockroach (Tarakanishche) In Quaestio Rossica. Vol. 4, № 1. P. 170-192. DOI 10.15826/QR.2016.1.148.

Цитирование: Golynets S. Sergey Chekhonin: The Sickle and The Hammer or The Monster Cockroach (“Tarakanishche”) // Quaestio Rossica. 2016. Vol. 4. № 1. P. 170-192. DOI 10.15826/QR.2016.1.148.

1 This article was prepared with the support of RGNF, project no. 15-04-00458.

(C) Golynets S., 2016

Quaestio Rossica • Vol. 4 • 2016 • № 1, p. 170-192 
caught an adult intonation of Chukovsky's fables; his illustrations to it became a kind of an alternative to the official Soviet heraldry created by him.

Keywords: Soviet symbols; Hammer and Sickle; Korney Chukovsky "Tarakanishche" (The Monster Cockroach); Soviet censorship; Aesopian language.

Над созданием в 1918 г. эмблемы РСФСР, ставшей четыре года спустя основой герба Советского Союза, работало несколько художников. Но законченный вид гербу и флагу Российской Федерации придал Сергей Васильевич Чехонин. Благодаря таланту едва ли не самого виртуозного из русских графиков емкий по смыслу и, конечно, неповинный в оказавшихся за ним жизненных реалиях символ нашел совершенную композиционную форму. Наследие Чехонина недостаточно исследовано. Автор настоящей статьи, основанной на изучении ставших библиографической редкостью изданий, иллюстрированных и оформленных Чехониным, на публикациях конца 19101920-х гг., на дневниках того времени, обращается к важнейшим страницам творчества мастера. Поклонников таланта Чехонина удивило, с каким энтузиазмом и увлеченностью он начал сотрудничать с новой властью, работать над советской эмблематикой. В статье отношение Чехонина к современным событиям рассматривается в русле темы «"Мир искусства” и революция». Сочувственно встретив свержение самодержавия, «мирискусники» готовы были и после Октябрьского переворота принимать активное участие в работе по охране архитектурных памятников и музейных сокровищ, по совершенствованию художественной педагогики, издательского и театрального дела. Однако вскоре энтузиазм сменился чувством тревоги и неудовлетворенности. В середине 1920-х гг. многие из «мирискусников» оказались за пределами Советского Союза. Не составил исключения и Чехонин. У художника нарастали критические и скептические настроения, наиболее полно проявившиеся в иллюстрациях к сказке Корнея Чуковского «Тараканище». Анализируя текст «Тараканища», сопоставляя его с другими сказками Чуковского, с дневниковыми записями писателя, автор статьи убеждает, что «Тараканище» адресован не только детям. Не случайно образ «Тараканища» в 1930-е гг. возник в роковом стихотворении Осипа Мандельштама («Тараканьи смеются глазища и сверкают его голенища...»), а в известной пьесе Евгения Шварца он вырос до размеров гигантского дракона. Чехонин, несомненно, уловил недетскую интонацию сказки Чуковского: его иллюстрации к ней стали своего рода альтернативой созданной им советской геральдики.

Ключевые слова: советская символика; серп и молот; Корней Чуковский; «Тараканище»; советская цензура; эзопов язык.

In 1918, a number of Soviet artists were working on the emblem of the RSFSR that became the basis for the Soviet coat of arms four years later. The people usually accredited with this work are Alexander Leo from St. Petersburg and Yevgeny Kamzolkin from Moscow [Иванченко, с. 53, 55], Natan Altman [Евсеев, с. 274-276]. However, it was Sergey Vasilievich Chekhonin who gave the coat of arms and the flag of the newly born Russian Federation their final form.

It has happened already, my dear boy, that our children growing up as sovetich $i$ (of the Soviet tribe) accept the sickle and hammer not as the newest and youngest 
of the state coats of arms, which replaced the centuries-old double-headed eagle after a terrible struggle; it is the only one that they have grown to know, the only one that accompanies them in their lives and therefore in their thoughts; it is the original and the indisputable one, without a beginning back in time or an end in the future; it is an expression of the solemn and immense power of the Russian state. Those who are the blood-kin of the Revolution will understand nothing of that feeling of bewilderment and distrust that accompanied ours - as the participants and bystanders of the 1917-1922 epoch - upon witnessing Chekhonin becoming the artist of the October coup [Эфрос, Пунин, с. 7].

Thus opens "The Master of Soviet Empire Style", an article written more than ninety year ago by Abram Efros, who labelled the post-October work of Sergey Chekhonin 'the road of Russian state art from the RSFSR towards the USSR' [Там же, с. 8].

Time has changed many things. The double-headed eagle has once again become a symbol of Russia. The emblem of the Soviet state was already in the late 1980s an object of Sots-art in the form of a famous risqué chastushka rhyme (Sprava - molot, sleva - serp, eto nash sovetskiy gerb, khochesh' zhni, a khochesh' kuy - vse ravno poluchish <...> ("On the right - a hammer, on the left - a crescent, this is our Soviet coat of arms. Reap if you want, or hammer if you wish - you will still get nothing (<obscenity >"). ${ }^{2}$ It was thus no longer thought of in terms of the pathetic lines of Samuil Marshak: Nerazdelimy serp $i$ molot, zemlya $i$ kolos'ya $i$ zvezda! ("Inseparable are the hammer and sickle, and the land, and the stalk, and the star!"). ${ }^{3}$ Efros' article, along with Nikolay Punin's “On the Mastery of S. V. Chekhonin", are part of a 1924 book that still remains the only one ${ }^{4}$ completely dedicated to the work of this artist. This book, designed by Chekhonin himself, was the fruit of the combined work of three important figures in Russian culture who were born in the Silver Age and found themselves in quite another epoch. Their destinies were bitter. Punin died in one of Stalin's camps. Efros fully experienced the severity of the regime whose birth he greeted with such ardour. Chekhonin's life

\footnotetext{
${ }^{2}$ In the original: «Справа - молот, слева - серп, это наш советский герб, хочешь жни, а хочешь куй - все равно получишь... <obscenity>”.

${ }^{3}$ In the original: «Неразделимы серп и молот, земля, и колос, и звезда!»

Quite notable is the juxtaposition of two movies both entitled "The Sickle and Hammer": the first was a propaganda film created in 1921 by Vladimir Gardin while the second was a Sots-art parody of Soviet movie stereotypes directed by Sergey Livnev in 1994.

${ }^{4}$ To this very day, the legacy of S. V. Chekhonin has not enjoyed the same attention in art and literature studies as his close peers in the late nineteenth and early twentieth centuries. Apart from the aforementioned book, we can name only a few publications that contain Chekhonin's works and some contemplations on his artistic style [Современная русская графика; Голлербах, 1922, №1; Голлербах, 1923, № 15-16; Русский художественный фарфор; Боцяновский; Эфрос, Пунин; Графическое искусство в СССР; Данько; Ехроsitioa Serge Tchékhonine chez A. Marchak; B. Е. W.; Эфрос, 1930; Ганкина; Искусство оформления книги; Сидоров; Лянда, 1972; Лянда, 1974; Милашевский; Советский фарфор; Андреева, 1975; Андреева, 1978; Петров; Герчук, 1978; Герчук, 1989; Герра, 1981; Евсеев; Липович, 1988а; Липович, 19886; Липович, 1990; Боулт; «Мир искусства», 1991; Голынец, 1994; Голынец, 1997; Голынец, 1999; Голынец, 2010; Сергей Васильевич Чехонин: каталог; Они унесли с собой Россию...; Кузнецов; «Мир искусства», 1898; Кудесник, чародей, приспособленец... ; Лейкинд, Махров, Северюхин, 1999; Домбровский].
} 
was cut short in 1936 when abroad, where he had emigrated four years after the publication of the book and where he also could not fully develop his artistic talents (Il. 1).

Chekhonin's post-October works bewildered his fans, who were used to seeing his work as purely aesthetic and fully detached from the social problems of the times. Chekhonin could not have been suspected of following a survival strategy out of fear of the regime: he had embraced the ideas of the Revolution back when conventional wisdom argued that it was better to wait out the turmoil. We should also rule out the explanation that dwells on the purely 'craft' character of Chekhonin's art, implying that the artist was indifferent

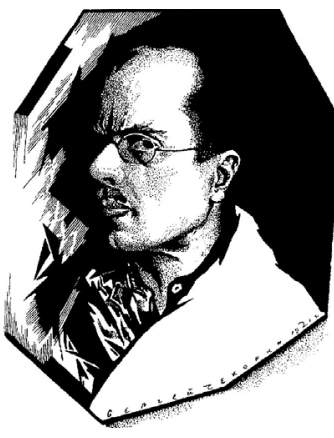

1. S. V. Chekhonin (1878-1936). Portrait. 1921

1. С. В. Чехонин

(1878-1936). Портрет. 1921 to what his 'virtuous hand' was drawing, whether it be aristocratic coats of arms, Soviet emblems, rose garlands for the Apollo magazine, or proletarian slogans. Efros and Punin both rejected such assumptions. Efros directly stated that:

Chekhonin... was never a mere professional. He could be "for" or "against", but he could never be "above" or "in between". His art is too emotional. He is more a poet than a master. It happens that his hand seems tired; however, his art is always thrilled by pathos. If he was with the Bolsheviks, he was so by the calling of his heart. If he brought here his traveling retrospective craftsmanship, the October coup was sounding in his ears with the same ringing that had always stirred his blood and grown from his Empire-style antiques; the one that was beating in the nerve centre of his art and was cast into images, flowered with forms, and constituted "Chekhonin's mystery”... [Эфрос, Пунин, 1924, с. 14].

Putting an edge onto his judgement, Efros describes Chekhonin as the only true artist of the Revolution:

...A sociologist can witness... a crowd of artists on the other shore who turned away [from the Revolution] - a few shamanistic futurists at the bottom of the steep hill on our side - and a lonely figure in an antique dress adorned by Soviet emblems, climbing the mountain together with the Revolution...

[Там же, с. 22] $]^{5}$.

\footnotetext{
${ }^{5}$ We should note that A. M. Efros did not arrive instantaneously at this understanding of Chekhonin's post-October art: in 1922, in one unpublished article, the critic wrote that this art was created 'not the way the revolutionary art should be created; not from the hearth of the revolution; it is rather an art of a random event, born by an incidental father from an incidental mother. Chekhonin is a typical artist of the Mir iskusstva magazine - fond of antique styles, a reproducer of the antiquity. As a civilian, he accepted the Revolution, came close to it and stayed with it. His artistic canons draw him to imitate the eighteenth century; his social inclinations to the Soviet system. Thus, he created emblems for the workers as if for powdered marquises, and he dressed up his formidable five-lettered creation in the style of the Louis dynasty. Does this charming curiosity have to represent revolutionary art in history?” [Эфрос, 1990, № 3].
} 
Chekhonin, who had in many ways defined the language of the imagery of the Revolution, is a unique figure. However, he shared a great deal of his artistic understanding of reality with other artists from the Mir iskusstva magazine, and his development cannot be understood separately from the trajectory of this magazine during the Revolution. In the publications issued during the first Soviet decades, studies usually stressed the alien and even hostile character of Mir iskusstva towards revolutionary events; however, from the beginning of the 1960s, when the time had come for the artistic 'rehabilitation' of this community, researchers tried to find those actions and citations of participants in Mir iskusstva that would show them as being close to Social-Democrat ideals, if not Bolshevik ones. ${ }^{6}$ However, in the post-Soviet era, scholars have uncovered new tendencies in the works of this community which are connected to the idealisation of pre-revolutionary Russia.

The majority of the Mir iskusstva community met the February Revolution with sympathy and even enthusiasm: “...I am happy [to witness] the bright dawn that rises in such glory over our homeland," - wrote Lev Bakst from abroad in the spring of 1917 [Цит. по: Пружан, с. 195]7. In the same year, Diaghilev commissioned Igor Stravinsky to write an orchestration of the song "Еy, uhnem" («Эй, ухнем») which was to be played as an introduction to a Russian ballet performance on 9 April 1917 in Rome instead of the tsar's anthem. On the title page of the score was the appellation "Hymn of the New Russia" and a drawing of a red flag provided by Picasso [См: Стравинский, с. 519-520]. This symbol was also put to music in Stravinsky's ballet The Firebird: in the final scene, Prince Ivan is crowned with a Phrygian cap and a red flag instead of a crown and a sceptre [см.: Ярустовский, с. 100]. On the pages of Le Figaro (14 May 1917), Diaghilev told a puzzled audience:

In Russia today, the red flag is the emblem of those who believe that the welfare of the whole world depends on the freedom of its peoples, achieved by victorious struggle alone...

[См.: Сергей Дягилев и русское искусство, с. 239].

Eyewitnesses of these events also experienced exhilaration. One characteristic piece of evidence is a painting by Boris Kustodiev entitled "27 February 1917", which depicts a state of festive excitement. Similarly excited records can be found in Konstantin Somov's diary entries from 1 (13 O. S.) and 4 (17) March (Somov was one of the most apolitical members of Mir iskusstva):

${ }^{6}$ All this being said, this research by no means wishes to belittle the value of the work of cultural scholars in terms of collecting factual material and connecting it to the studied topic with a multitude of interesting speculations. I will specifically note one fundamental study: [Лапшин].

In the original: «...Как счастлив светлой заре, которая так славно загорается над нашей родиной». 
The street is full of people, there's order, it's fun, and the mood is uplifting. $<\ldots>$ The people welcomed a regiment of sailors, I felt fun and joy. Together with the regiment, we marched along the whole of Morskaya Street. <...> So many events in just two days. Nicholas has been put down, we will have a republic. My head is spinning. I was so afraid that the dynasty would stay <...> I saw how the royal coat-of-arms was being knocked down from all the shop signs. $<\ldots>$ This morning I called Benois, advising him to take power directly into his hands in the sphere of the arts...

[Константин Андреевич Сомов, с. 174-175].

Benois himself had a quite different perception of events. In a diary entry from 3(16) March, he wrote:

If today no one cries over the monarchy, tomorrow even those who have attached red ribbons and sincerely consider themselves revolutionaries will cry...

[Бенуа, с. 55].

However, on the next day, dropping his usual scepticism, Benois confessed:

On the other hand, the perspective that opens in front of me is not without a certain grandiosity. Even a call of duty of a sort awakens in me... Much of what can be done now, particularly in the sphere of the arts, can only be done with my close participation and, often, leadership. And so I have taken on this duty, although I foresee that all future activity will be a complete disappointment. Oh, if only Diaghilev was here, too!

[Там же].

Thus, Mir iskusstva was clearly competing for leadership of the arts in Russia, actively protecting architectural monuments and museum treasures, transforming artistic pedagogy, publishing, and continuing with theatre business. However, their enthusiasm soon gave way to feelings of concern: the October coup and subsequent events were met in quite a different spirit. Eugene Lanceray, who in 1905 had reproached Benois for his "fear of socialism" [Цит. по: Гомберг-Вержбинская, с. 113], was proclaiming in February 1917 that there was "amazing joy and happiness in my soul!" [Op. cit.: Подобедова, с. 170]. Nevertheless, he later became a member of Denikin's "Osvag" and the author of White Guard posters. Ivan Bilibin, his ex-colleague in the satirical magazines Zhupel and Adskaya pochta who had been was arrested in 1906 because of his daring caricatures of the autocratic authorities, in the summer of 1917 created a sketch of the new Russian coat-of-arms: a two-headed eagle which had lost its crown. However, he left Petrograd one month before the October coup. He wished his friends "all the best. Have a happy life" before going to the Crimea. He then emigrated to Egypt in 1920 [Иван Яковлевич Билибин, с. 109]. 
Many of the members of Mir iskusstva who stayed in Petrograd after October 1917 continued and even intensified their artistic and cultural activities. They were not stimulated merely by the need to earn their daily bread. Emphasising that he was a "lousy socialist", Benois wrote on 9(22) November 1917:

...I am motivated by the call to help those people who are now in charge of so many things and who had received in their supervision many things totally alien to them, those very things that to me are the dearest of all in the whole world. $<\ldots>$ They can have in their possession grandiose means that can lead to grandiose changes. $<\ldots>$ I am again harbouring various projects and expectations. Firstly, the expansion of the Hermitage at the expense of the Winter Palace, the creation of a grandiose portrait gallery of Russian history, and so on. There are also projects of a more general character, including those that were ripening for quite a long time...

[Бенуа, 1996, с. 43-44].

Apparently, Chekhonin was not the only one for whom the epoch was "buzzing in the ears". The creativity of the members of Mir iskusstva received unexpected momentum with the realisation of the grandiose scale of the historic changes, the crushing of the old regime, and the contemporary sentiment of enlightenment. It would otherwise be hard to explain the eagerness of Mstislav Dobuzhinskiy and Alexander Benois when they created the theatre of heroic drama in Petrograd (the Bolshoi Drama Theatre) or the rise of book illustrations in the Mir iskusstva circle in the late 1910s and 1920s.

It would be incorrect to conclude that the members of Mir iskusstva completely accepted the ideas of Bolshevism. Even Kustodiev, who most closely followed revolutionary themes, was far from these ideas. His "Bolshevik" (1920), which visibly appropriated the techniques of mass propaganda and was the source of several Soviet paintings, was nevertheless 'suspiciously' close in its composition to a 1905 drawing named "The Entry", which depicts a giant skeleton, symbolising death and devastation, rising above Moscow streets and crowds. However, let us not completely fall for the analogy. The hero of the 1920 drawing, a stern, bearded man with a huge crimson banner, is a synthesis of the centuries-old traditions of Kustodiev's Russia as well as their destroyer.

Chekhonin, the most refined stylist of all the members of Mir iskusstva, but only a provincial in his art and everyday life, was singled out for his “"narodovoltsy' and democratic" sympathies [Милашевский, с. 179-180]. In his younger years, Chekhonin was close to the family of Gleb Uspenskiy and, later, to Maksim Gorky, which makes clear his susceptibility to socialist ideas and his keen interest in the events of October. It was Chekhonin who designed a 1923 cover to John Reed's 10 Days That Shook the World.

However, Efros describes Chekhonin not merely as an artist of the Revolution, but also of Soviet statehood. The idea of statehood was usually opposed to revolutionary aspirations, although the Russian intelligentsia 
accepted it in a plurality of ways. This idea began to emerge among the intelligentsia in the wake of the events of 1905-1907 and especially during the First World War. It involved some of the members of Mir iskusstva, for which they were later subjected to vulgar sociological criticism. Chekhonin united in himself opposite tendencies. In the early 1920s, his position could have found support in the views of the smenovekhovtsy movement, which was calling for the support of the Soviet state in the hope for its inner rebirth and the fulfilment of their dream of a strong Russian state.

Chekhonin was blowing his Empire-style forms as if they were battle horns. He called for an assembly with a bugle. He was calling for heroes. He was prophesying victory. He was lauding the great power of the government. He was the Master of the Empire in its original sense, in its only sense. $<\ldots>$ Thus, the sentiment for statehood started to awaken, the penchant for the monolith of millions of civic wills, cast together in a firm explosive shell and thrust in one direction, which in its own time has shaped equally the heavy pace of Rome and the easy rapidness of France. <...> It was an instinctive thrust.... towards the future. $\langle\ldots\rangle$ He witnessed how the expanded, weakened colossus of the Russian Empire, if only for a few historical moments, was unexpectedly filled with state will, stood up tall, swung its body in a long-forgotten gesture of youth - and collapsed as if an egg containing the life of the immortal fairy-tale wizard Koschey had been broken right in front of him. He was witnessing how the Revolution, taking hold of the centrifugal powers of the collapse, rose as the new power and began assembling the new state. <...> In Chekhonin's artistic vision, the dishevelled, blocked, and hungry Soviet state was already standing tall, firm, complete, and flourishing with gorgeous classical forms...

[Эфрос, Пунин, с. 16-22].

Efros was undoubtedly sincere in his admiration: his ecstatic observations are typical socio-political fantasies of the first post-October years. Conformism came only later into Soviet art criticism. However, in his insistent glorification of the new idol, in juxtaposing Chekhonin's confident stride with the doubts and confusion of other members of Mir iskusstva, Efros sounded as if he was trying to convince not only the reader but also himself that the principles of the old humanist ideas were outdated and no longer necessary. Punin touched upon the same topic:

On the whole, the artistic life of these decades (1890s -1900s. - S. G.) was like a dawn of a great era in Russian 'classicism'... At the beginning of the twentieth-century 'humanistic era', which had... a private individual at its core, was completing its circle... and a world of different values, not typical of classical humanism, had erupted through the haze and chaos of our time. <...> We are not sure that it will include the majority of those artistic values that seemed so impeccable in the late nineteenth and early twentieth centuries. Yet these values are at the basis of the variety of artistic and technical traditions of which Checkonin has always been a custodian. <...> Therefore, determining the place 
of Chekhonin in contemporary art, we can say that this is one of those artists who... belong to the prosperous, century-long era of Russian classicism...

[Эфрос, Пунин, с. 38-40].

It seems that Punin, who, unlike Efros, considered Chekhonin not as the beginning but rather as the climax of a great artistic trend, was right. Of course, in Chekhonin's works in the post-October years, one can see the anticipation of the neoclassical trend of the 1930s-1950s; in this sense, the artist made a 'dash for the future', but not the future which Efros had in mind. Turning away from delicate porcelain and book pages to giant canvases and urban space, the Soviet Empire style, nicknamed by a popular joke as Ampir vo vremya chumy («Ампир во время чумы» / 'Empire in time of plague') [See: Золотоносов, 1998, с. 10-13], became the expression of the anti-human essence of the totalitarian state. Chekhonin, who left the Soviet Union in 1928, had no relation to it (Il. 2).

Influenced by the Mir iskusstva movement, Chekhonin's romanticism in his post-October works movement, is especially noticeable if compared with the art of mature totalitarianism. Chekhonin was sensitive to both the artistic achievements of the past and the success of the latest trends, interpreting both in the spirit of exquisite stylisation, in the spirit of Mir iskusstva. Chekhonin's art was at its most expressive when he achieved an unexpected combination of classic forms and motifs with the methods of 'leftist' art, ranging from the Suprematism of Kazimir Malevich to the 'Okna ROSTa' (Окна POCTa) of Vladimir Lebedev. Efros noted:

He [Chekhonin] creates an RSFSR emblem that is entwined with the flower garlands of the departed century as well as with the shifts and gaps in the futuristic aesthetics of the 1918-1919, and rigid sketches of the somewhat completed pediment of the Soviet state...

[Эфрос, Пунин, с. 22].

The question remains, however, whether Chekhonin's post-October art was entirely festive and jubilant: did the artist see alternative imagery behind the 'youngest coat-of-arms in the world'? Neither Efros, nor Punin wrote about this. At the same time, Chekhonin's work of the late 1910s early 1920s, as well as the work of his colleagues from Mir iskusstva, also registered many tragic notes in the perception of their times. It would suffice to recall a decorative porcelain piece dedicated to the famine of 1921 in the Volga region. These works are not only a response to a particular disaster, but also a sorrowful introspection on the historical fate of Russia. It is hard to label these works, much like many of the decorative pieces created in roughly the same period by Chekhonin's younger colleague, Alexandra Shchekatihina-Pototskaya, as mere agitfarfor (агитфарфор / agitational porcelain). Dramatic mood is also very distinguishable in Chekhonin's portraits; for example, in the 1918 "Portrait of Mother", which has something in common with the images in Boris Grigoriev's "Russia". 
The grotesque and satire in Chekhonin's post-revolutionary work are closely linked to the aforementioned thematic. The satirical aspect is manifested in well-known works that are, rather unfortunately, little studied today. Its origins are in the cartoons for the Zritel', Maski, and Almanakh («Зритель», «Маски» и «Альманах») magazines from 1905-1906 (Chekhonin was one of the pioneers of satirical drawings during the first Russian Revolution). This theme was continued in drawings for Satyricon («Сатирикон»), in the stage works for the Krivoe zerkalo («Кривое зеркало») theatre company, and in the fantastic monsters of the $1919 \mathrm{Az}$ buka («Азбука»). It culminated in the illustrations for a children's book in the 1920s which was not entirely for children: the illustrations for The Cockroach (The Monster Cockroach), a satirical poetic fable by Korney Chukovsky. At first sight, The Cockroach is a humorous poem, reminiscent of children's nursery rhymes: take, for instance, the line Yekhali medvedi na velosipede («Ехали медведи на велосипеде» / “The bears were riding a bicycle"). However, on a deeper level, it is possible to perceive mockery: Pokorilisya zveri usatomu... («Покорилися звери усатому...» / "The animals surrendered to the moustachioed one..."). This work was reprinted in huge quantities throughout the Soviet years simply because it was too risky to even contemplate the possible allegory. The Cockroach was composed along with Moidodyr («Мойдодыр») in 1922: in the following year, both fables appeared on Petrograd book counters as separate brochures, the first one illustrated by Sergey Chekhonin, the second one by Yuri Annenkov. This marked the beginning of a 'fable' decade in Chukovsky's writing. Chukovsky had already published a fable entitled Krokodil («Крокодил») that he had started in the pre-revolutionary era and released in 1919 with illustrations by Re-Mi. This work, momentarily becoming popular and even famous, saw severe censorship in subsequent editions. Censorship raised the sincere ire of the author, who denied the presence of any political allusions in his poems. Chukovsky's fables, playful and filled with joy, are indeed primarily aimed at children. However, in the works of the 'cunning' Korney Ivanovich, there certainly is something that is not addressed to children, or, at least, not merely to children. ${ }^{9}$ Chukovsky, as much as many of his col-

\footnotetext{
${ }^{8}$ An informative article by V. V. Maroshi, "Zoos in the Russian literature of the $19^{\text {th }}$ - the beginning of the $20^{\text {th }}$ centuries: Between Heaven and Hell" introduced The Crocodile by K. I. Chukovsky into this topic [Мароши].

${ }^{9}$ Comparatively recent publications of new data connected to K. I. Chukovsky and his diaries [Чуковский, 1991; 1994], as well as memoirs about him [Ильина, Шварц], have stimulated the desire to rethink his artistic heritage and to reread seemingly familiar fables. Following M. S. Petrovskiy's monograph, Knigi nashego detstva (Our childhood books) (M., 1986), unexpected and even paradoxical articles have appeared in print. [Гаспаров; Золотоносов]. The idea for this article came about as a result of collaboration with O. A. Bogomolova over the preface and commentary to the reprint edition of Chukovsky's The Cockroach with illustrations by Chekhonin within the series Izbrannyye detskiye knigi sovetskikh khudozhnikov («Избранные детские книги советских художников» / Selected childrens' books of the Soviet illustrators), which was originally published in the 1970s-1980s by the Sovetskiy khudozhnik ("Советский художник») publishing house and edited by Yu. Ya. Gerchuk. This work was interrupted due to the end of the series, and will be continued when commissioned by another publisher.
} 
leagues, was seeking to be loyal to the new order. One proof of this can be found in a diary entry from 1924 which describes a meeting between Aleksander Serebrov-Tikhonov, who became an editor of Russkiy Sovremennik («Русский современник»), and the employees of the future magazine:

I am asking you to tell me straight-forwardly if you are planning to attack Soviet authority, even if secretly, partly, or vaguely. Then it would be impossible to even start the magazine." All of us answered 'no', Zamyatin also answered 'no', although not as energetically as Efros... ${ }^{10}$

[Чуковский, 1991, с. 271].

It is difficult to make a judgement about the true political sympathies of Chukovsky, even after the publication of his diary. In the first place, the character of this writer was ambiguous; moreover, at that time, one could not put much trust into paper, and as a result, 'safe' entries often appeared. Yet there is no reason to disbelieve entries such as those concerning the former summer residence of the lawyer Gruzenberg:

I remember how tedious and desolate was the life of the owners of this summer estate. <...> Their daughter Sonia wandered between the splendid rooms sour, sleepy, dispensable, and bored. There were endless visits of some uninteresting guests, cousins, relatives, helpers and barr[isters]. $\langle\ldots\rangle$ And now, strawhaired, naked, suntanned kids, happy with the air, the sun and the sea, are everywhere. I read them Moidodyr and The Cockroach...

[Чуковский, 1991, с. 281].

It seems that Chukovsky focused all of his dissatisfaction with the emerging Soviet system on censorship alone. Nevertheless, his records gradually started to expose the features of the anti-human regime:

I'm beginning to understand people who drink vodka. <...> Now it so happened that all creativity takes up merely $1 / 10$ of one's energy, and 9/10 of the energy go into protection of their rights as creator," confessed Chukovsky in 1926 [Чуковский, 1994, с. 370].

An exemplary story is the writer's visit to Isaac Brodsky, one of the founders of Socialist Realism who had once been close to Chukovsky:

...To live comfortably and lavishly, one has to perform the "shootings" and to fabricate Lenin, Lenin, Lenin. Here again, the philistine, defending their right to the middle-class life, is covering themselves up by an extrinsic psychology [Чуковский, 1995, с. 370].

${ }^{10}$ Apparently, it was then that a popular joke about Chukovsky started circulating: "Publisher Suvorin had asked Chukovsky: With the revolution happening right now, we need new trends. Whom should we publish? - Publish Kropotkin. He is a revolutionary and a prince - never a miss, whatever the outcome of the events" [Цит. по: Русское богатство, c. 167]. 
Protest against the smug middle class, traditional in Russian literature and among the Russian intelligentsia, was for Chukovsky associated with the mockery of philistine cowardice. This was first enunciated in The Crocodile (1917):

Kto, drozha ot strakha, skruchilsya v chulane,

Kto $v$ sobachyey budke, kto na cherdake...

Papa skhoronilsya $v$ starom chemodane,

Dyadya pod divanom, tetya $v$ sunduke.

Vse sidyat $i$ molchat

I, kak zaytsy, drozhat,

I na ulitsu nosa ne vysunut. ${ }^{11}$

(Who, trembling with fear, curled up in the closet,

Who's in a doghouse, who's in the attic...

Dad hid himself in an old suitcase,

Uncle under the sofa, aunt in the antique chest.

All sit silent

And tremble, like rabbits,

And no one dares sticking their nose out on the street.)

(The Crocodile)

This same satirical image was put into the fables of the 1920s:

I sidyat, i drozhat pod kustochkami,

Za bolotnymi pryachutsya kochkami.

Krokodily v krapivu zabilisya,

I $v$ kanave slony skhoronilisya.

Tol'ko i slyshno, kak zuby stuchat,

Tol'ko i vidno, kak ushi drozhat.

A likhiye obez'yany

Podkhvatili chemodany

I skoreye so vsekh nog

Vrassypnuyu nautek. ${ }^{12}$

(They sit and shiver under the bushes,

They hide behind the swamp hassocks.

The crocodiles buried themselves in nettles,

And the elephants jumped in the ditch.

Only the chattering teeth are heard,

Only the shaking ears are seen.

As for the daring monkeys,

${ }^{11}$ In the original: «Кто, дрожа от страха, скрючился в чулане, / Кто в собачьей будке, кто на чердаке... / Папа схоронился в старом чемодане, / Дядя под диваном, тетя в сундуке. / Все сидят и молчат / И, как зайцы, дрожат, / И на улицу носа не высунут».

${ }_{12}$ In the original: «И сидят, и дрожат под кусточками, / За болотными прячутся кочками. / Крокодилы в крапиву забилися, / И в канаве слоны схоронилися. / Только и слышно, как зубы стучат, / Только и видно, как уши дрожат. / А лихие обезьяны / Подхватили чемоданы / И скорее со всех ног / Врассыпную наутек». 
They've picked up their suitcases,

And rushed away,

Scattering around.)

(The Monster Cockroach / «Тараканище»)

A kuznechik, a kuznechik,

$\mathrm{Nu}$, sovsem kak chelovechek,

Skok, skok, skok, skok

Za kustok

Pod mostok

I molchok! ${ }^{13}$

(A grasshopper, a grasshopper,

Well, he's just like a man:

Skip, skip, skip, skip -

Behind the bush,

Under the little bridge,

And hush!)

(Buzzer Fly / «Myxa-u,окотуха»)

However, Chukovsky, who was, according to Evgeny Shvarts, "distantly related to the upas tree" [Шварц, 1990, с. 270], not only flung poisonous barbs at philistinism itself, but also parodied its critics, the whistleblowers:

Ne proklinayu palachey,

Ni ikh tsepey, ni ikh bichey.

No vam, predateli-druz'ya,

Proklyat'ye posylayu ya!

My kazhdyy den' i kazhdyy chas

Iz nashikh tyurem zvali vas,

I zhdali, verili, chto vot

Osvobozhdeniye pridet. ${ }^{14}$

(I do not curse the hangmen -

Neither their chains, nor their whips.

But to you, my traitor-friends,

I send a curse!

We've called upon you

Every day and hour from our prisons;

We've waited, we've believed that soon

The liberation will come.)

(The Crocodile)

\footnotetext{
${ }^{13}$ In the original: «А кузнечик, а кузнечик, / Ну, совсем как человечек, / Скок, скок, скок, скок / За кусток, / Под мосток / И молчок!»

${ }^{14}$ In the original: «Не проклинаю палачей, / Ни их цепей, ни их бичей. / Но вам, предатели-друзья, / Проклятье посылаю я! <...> / Мы каждый день и каждый час / Из наших тюрем звали вас, / И ждали, верили, что вот / Освобождение придет».
} 
What is this: Lermontov, Ryleev, or Nekrasov?

As for the zoological allegories in The Monster Cockroach, are there none of the mitigating tropes hinting at the characters in Gorky's Song of the Stormy Petrel? Let us remember the "silly penguin, who feebly hides his fat body in the rocks" or "moaning loons" who "can not access the delight of life in battle."

The ironic Chukovsky did not hesitate to parody himself either. After all, the 'heroic Vanya Vasilchikov', who was almost turned into a Komsomol leader by Soviet filmmakers [Чуковский, 1995, с. 259], mirrored images from the patriotic literature of World War I (Russkiy nemtsu zadal pertsu ${ }^{15}$ / The Russian has punished the German); in its turn, the sparrow, who "took it up and pecked the giant, and so there's no more cockroach" is a selfparody of Vasilchikov.

However, behind all these games for adults and children, behind the reflections on the murky facts of a time unbeknownst to us, a feeling of danger oozes from The Monster Cockroach. It seems unlikely that Chukovsky had in mind a certain moustachioed and powerful person as early as 1922. Nevertheless, cockroaches of various levels of importance, capable, in all their inner vacuity, of stirring up an atmosphere of fear, were undoubtedly at the forefront of the author's inner vision. As a true artist, he captured the macabre tendency of the times, notably so in the lines Zveri ot ispuga skushali drug druga ${ }^{16}$ ("The animals have eaten each other out of fear"). Subsequently, life itself had a chance to illustrate this fable.

So, how did Chekhonin illustrate this? ${ }^{17} \mathrm{He}$ had no centaurs, no disguised animals in human clothes, although such methods were familiar to this master of political satire. His fanged, horned, and furry characters look surprisingly authentic. Any animal illustrator can envy the craftsmanship with which Chekhonin rendered the movements and habits of animals, birds, fish, and insects. Nevertheless, the grotesque character of the images makes the work a fantastical bestiary rather than a zoological almanac. The artist was even more mocking and ironic than the author of the fable: the heroes of the illustrations do not provoke any sympathy or delight. "They ride and laugh, chewing on gingerbread cookies": these lines should cre-

\footnotetext{
${ }^{15}$ In the original: «Русский немцу задал перцу».

${ }^{16}$ In the original: «Звери от испуга скушали друг друга».

${ }^{17}$ Chekhonin was not chosen randomly as the illustrator of Chukovsky's fables. The writer and the artist met each other occasionally in the mid-1900s in the various publishing houses of St. Petersburg. Their collaboration started in 1912, when Chukovsky invited Chukhonin, along with a few other artists to illustrate children's almanac Zhar-ptitsa (Жapnтица), and continued in 1917 during the work on another almanac, Elka. During his work on illustrations to The Monster Cockroach, Chekhonin drew a caricature portrait of Chukovsky, depicting him in the moment of cheerful polemic [See: Чукоккала, с. 309]. Subsequently, the artist created a few more portraits of Chukovsky; the latter wrote about one created at the beginning of 1923: "My portrait turns out very good - the eyes are guilty, the face is feeble; there is great likeness" [Там же, c230]. Chukovsky was attracted by the high artistic culture of the masters of the Mir iskusstva community to which Chekhonin belonged: he liked their attention to the visual imagery in children's books and their attempts to make the books witty and amusing and to drain them of the boring moralising and edification that was so widespread in works for junior audiences.
} 
ate the sense of an idyll, similar to the ending of The Crocodile. However, the image shows the animals rushing in front of the spectator in a fierce and senseless manner: they are shrieking, grinning with bared teeth, their manes and tails are flying in the wind; the sudden appearance of a tiny, unabashed, moustachioed creature stops this movement; then, the instance of fear is replaced by ever increased aggression, which turns into a cowardly flight and the onset of total humiliation. Paradoxically, even when the tyrant is removed, Chekhonin's interpretation does not look like a joyful celebration; the illustrations of wild dancing scenes are followed by a cruel scene where a tearful moon is attached to the skies with a hammer and nails. Faithful to the linear graphic style of the Mir iskusstva community, Chekhonin's brush attained a greater dynamism and diversity in conveying different textures in The Monster Cockroach. It tossed the strands of lions' manes as if they were in flames, it twisted a running dog's tail into a dynamic spiral, it foamed with curly strokes on the skin of a bumpy toad, and it scattered a cascade of short curls on shaggy bear fur. The visual creativity of this master and the richness of his ornamentation seem inexhaustible. How exquisitely he twists a snake, whose patterns combine a mesh of the finest lines and decorative ovals! How gentle is the pattern of curls on a leopard's head! How perfectly accurate is a curve at rendering predatory grace! How refined is the interplay of white and black spots on swamp water that mirrors the moon!Admiration for Chekhonin's skills notwithstanding, Chukovsky was unhappy with his illustrations for "The Monster Cockroach". We do not know the exact reasons for his dissatisfaction. ${ }^{18}$ One might be that the writer did not like the excessive 'adultness' of the drawings and their disparity with the text. In contrast to the illustrators of the next generation (Re-Mi, Annenkov, and Konashevich), who perfectly caught and reflected the running, jumping rhythm of Chukovsky's fables and the cinematic character of his writing, Chekhonin almost entirely skips any interaction throughout the entire series, using only energetic diagonals to hint at movement. However, the independence of the illustrations and the tension of Chekhonin's brush, which is combined with the precision of every stroke, is almost palpable, giving the images a special suggestiveness. It is sufficient to look at the 'shaking' scene: one really ...tolko i slyishno, kak zuby stuchat, tolko i vidno, kak ushi drozhat ("...merely hears the chattering teeth, merely sees the trembling ears") ${ }^{19}$ Behind the tiers of sketchy slides, there are lurking beasts: the only visible parts are legs, heads, ears, and tails. Intermittent zigzags and wavy lines radiate from the fable characters like fluids of fear, like universal angst.

Chekhonin sometimes consciously stylises and parodies his own routines for the sake of satire. The drawings of animals dancing in circles around the fearless sparrow are clearly reminiscent of wreaths and garlands in the Em-

18 "Chekhonin agreed to illustrate my book Fifty Piglets, and so I articulately and frankly told him why I disliked his illustrations to The Monster Cockroach. He accepted my words favourably and agreed to work in a different manner" [Чуковский, 1991, с. 261].

${ }^{19}$ In the original: «...только и слышно, как зубы стучат, только и видно, как уши дрожат...» 
pire style favoured by the master. However, here they are made not of lush roses, but of animal bodies and heads, of their trunks, tails, and horns.

Chekhonin created a sort of concentrated reading of the fable in the cover drawing, the only one in the series where, along with black, he uses pink and green. The composition is in the form of the oval so characteristic of Chekhonin. The letters that form the author's name and the title of the fable make up an arc-de-triomphe with their pointed spikes and firm lettering, crowning the whole scene. The scene was conceived by the artist himself: a disgusting, gigantic, moustachioed monster sits on the neck of a sad little teddy bear, while, on the right and left of the composition, there are two monkeys, fanning the tyrant with green branches. The arch of the title is recalled in the outlines of the cockroach's moustache, in the monkey tails, and in flexible twigs and blades of grass. The rounded contours of a hippo and an elephant, placed at the bottom of the foreground, also repeat the arch. The strongest in the animal world have fallen in front of the villain on their front legs, and are depicted with deadly irony. Their massive bottoms face the spectator and are decorated with juicy blush and cowardly tails. Energetic and dense lines boldly accentuate their sumptuous forms, while the perspective emphasises the common features of fatbottomed and thick-skinned cowards (Il. 3).

"A triumph of nothingness": this is the theme of this drawing. With its harsh combination of font and visual elements, it creates associations not only with Chekhonin's early book and magazine graphics, but also with his agitational porcelain. The heraldic character of the central image of the Monster Cockroach allows one to accept it as an alternative to the Hammer and Sickle, thus reflecting new aspects of Chekhonin's relation to contemporary reality as the "master of Soviet Empire style": these were missed by the critics of the twenties.

These facets of Chekhonin's worldview are also manifested in the artist's later works, perhaps most clearly in the little-known illustrations to the tale by Elizaveta Polonskaya entitled The Guests, published as a thin brochure by the Kniga publishing partnership one year after The Monster Cockroach. Polonskaya's text, written under the obvious influence of Chukovsky's fables but lacking their ideas and humour, is simply meaningless without a background knowledge of literary life at the beginning of the 1920s. The tale is now quite forgotten; however, Chekhonin's illustrations are undoubtedly worthy of attention. In this work, Chekhonin, freely drawing with a soft lithographic pencil, 'futuristically' incorporating various aspects into one composition, and actively playing with page spreads, departed even more clearly from the style of his earlier Mir iskusstva book illustrations than in The Monster Cockroach. Using the story of how animals and animated objects fire bitter insults at Karabek 'the brute', Chekhonin creates drawings of diabolic, absurd, and senseless brutality. Combining the grotesque with tactility, the illustrations to The Guests are in line with expressionistic trends of those years, and even anticipate the artistic phenomena of later periods. 
Further work with Chukovsky did not prove as fruitful for Chekhonin. Illustrations to those folk songs and rhymes rewritten for children by Chukovsky (Fifty Piglets, Zakalyaka, Home, etc.) are accomplished with the usual mastery, but they are not noticeable among Chekhonin's works. Chukovsky preferred to give the job of illustrating his newer fables to younger artists. The Cockroach ran through nine editions with Chekhonin's drawings, but after 1928 it started to be published with illustrations by other artists.

During the late twenties and the early thirties, Korney Ivanovich embarked on a censorship struggle with the 'chukovshchina': along with political critique, his fables were accused of preaching middle-class values and mysticism. The end result was a complete rejection of the necessity of fiction for children. The absurdity of Proletkult theories, thankfully, soon manifested itself; Chukovsky's fables have entered children's reading material once again, and he has been recognised as a master of Soviet literature. However, this did not save him from the ordeal of censorship for long years to come.

The illustrators of The Monster Cockroach that replaced Chekhonin (Dmitry Mitrokhin, Vladimir Konashevich, Aminadav Kanevsky, etc.) did not let any 'adult' hints slip into their work. However, reality itself has forced us to see that The Monster Cockroach is more than just a fable.

Tarakani smeyutsya glazischa

I siyayut ego golenischa. ${ }^{20}$

(The Cockroach's eyes are laughing,

and the shafts of his boots are shining).

The reference in these lines, written by Osip Mandelshtam in 1933, to Chukovsky's seemingly innocent verses has been already noted [cm., например: Бореев, с. 15, 20-21]. However, no one has paid attention to the connection between The Cockroach and The Dragon by Evgeny Shvarts, who, in the early twenties, served as Chukovsky's personal secretary and received his blessing for future literary work.

The history of the creation of The Dragon is quite interesting. This play was designed during the pre-war period to be anti-fascist; it premiered in 1944 during the Moscow tour of Leningrad Comedy Theatre, after which it was immediately banned. Nikolay Akimov, the play's director, wrote twenty years later: "There was no motivation provided; a long time since, it turned out that some extra-careful administrator saw in the play that which was not present in it at all." [Акимов, с. 232]. It is clear that the 'extra-careful administrator' saw in the play exactly what the censors were afraid to see in The Monster Cockroach, which had grown into a full-blown dragon by that time. The whole truth about the play's idea could not be articulated even in the sixties. However, The Dragon, along with other fable-plays by Shvarts, actively entered

\footnotetext{
${ }^{20}$ In the original: «Тараканьи смеются глазища, / И сияют его голенища».
} 
'anti-cult' art during the 'thaw'. Somewhat later, 'adult' readings of Chukovsky's fables also appeared, such as Rolan Bykov's movie Aybolit and Adolf Shapiro's play Chukokkala, staged in the Riga Theatre for Young Spectators.

Under the harsh conditions of Soviet censorship, literary and, in particular, fantasy images often took on the form of Aesopian parables. During the seventy years of Soviet art, opposition to the dogmas of socialist realism did not disappear. Naturally, the most important aspect of this sometimes instinctive, but more often conscious opposition was an appeal to universal themes in people's lives, to true spiritual values, rather than the use of political allusions and allegories. However, our understanding of the artistic culture of the Soviet era would be incomplete without taking into account the Aesopian language intrinsic to it. This allegorical language took shape at the same time as Bolshevik censorship, and the sinister image of the Cockroach immediately followed the Hammer and Sickle.

\section{Список литературы}

Акимов Н. Наш автор Евгений Шварц // Житие сказочника. Евгений Шварц: Из автобиографической прозы. Письма. Воспоминания о писателе. М. : Книж. палата, 1991. C. 227-234.

Андреева Л. В. О последних годах творчества С. В. Чехонина // Советское декоративное искусство' 76. М. : Совет. художник, 1978. С. 230-248. $240 \mathrm{c}$.

Андреева Л. В. Советский фарфор: 1920-1930-е годы. М. : Совет. художник, 1975.

Бенуа А. Выбранные места из дневника 1916-1918 годов // Мир музея. 1996. № 5. C. 52 .

Бенуа А. Выбранные места из дневника 1916-1918 годов // Мир музея. 1996. № 6. C. 43-44.

Борев H. Автобиография «Воскресшего из живых» // Русское богатство. 1993. № 2. С. 6-17.

Боулт Дж. Э. Художники русского театра: 1880-1930. М. : Искусство, 1990. 112 с.

Боияновский В. Художник двух революций // Былое. 1925. № 1. С. 237-258.

Ганкина Э. 3. Русские художники детской книги. М. : Совет. художник, 1963. 278 с.

Гаспаров Б. М. Мойдодыр // Новое лит. обозрение. 1992. № 1. С. 304-319.

Герра Р. С. Чехонин - мастер русской графики // Русский альманах. Париж, 1981. C. 184-187.

Герчук Ю. Я. Искусство Сергея Чехонина // Творчество. 1978. № 2. С. 20-23.

Герчук Ю. Я. Орнаменталист революции // Герчук Ю. Я. Художественные миры книги. М. : Книга, 1989. С. 149-153.

Голлербах Э. С. Чехонин // Казанский музейный вестник. 1922. № 1. С. 188-194.

Голлербах Э. Чехонинская школа фарфора // Сполохи. 1923. № 15-16.

Гольнец С. Бакст, Билибин, Чехонин: этапы становления и развития мирискуснической графики // С. П. Дягилев и современная культура : материалы междунар. симп. «ХІІІ Дягилевские чтения». Пермь : От и До, 2010. С. 73-79.

Гольнец С. Сергей Чехонин: Серп и Молот и Тараканище // Вопр. искусствознания. 1994. № 1. С. 295-299.

Гольнец С. Серп и молот и Тараканище у истоков советского искусства // Екатеринбургский гуманитарий : науч. альм. 1999. № 1. С. 71-92.

Гольнец С. Чехонин Сергей Васильевич // Русское зарубежье. Золотая книга эмиграции : Первая треть ХХ века : энцикл. биогр. словарь. М. : РОССПЭН, 1997. C. 695-698.

Гомберг-Вержбинская Э. П. Русское искусство и революция 1905 года : Живопись. Графика. Л. : Изд-во ЛГУ, 1960. 175 с.

Графическое искусство в СССР: 1917-1927. Л. : Изд-во Ленинград. акад. художеств, 1927. 294 с. 
Данько E. С. В. Чехонин // Мастера современной гравюры и графики. М. ; Л. : Госиздат, 1928. С. 61-65.

Домбровский $A$. Чехонин: между кругом и квадратом // Проектор. 2010. № 2 (11). C. $40-47$.

Евсеев М. Ю. «Почтовое ведомство заказало нашим художникам...» : К истории проектов первых советских почтовых марок // Панорама искусств'9. М. : Совет. художник, 1986. С. 272-276.

Золотоносов М. Ахутокоц-ахум // Новое лит. обозрение. 1992. № 2. С. 262-282.

Золотоносов М. «Фоминки» по классицизму : Фантазия на архитектурные темы // Новый мир искусства. 1998. № 2. С. 10-13.

Иван Яковлевич Билибин : Статьи. Письма. Воспоминания о художнике / ред.сост., автор вступит. ст. и коммент. С. В. Голынец. Л. : Художник РСФСР, 1970. 376 с.

Иванченко A. B. Союз Серпа и Молота : Государственные символы РСФСР. М. : Совет. Россия, 1987. 158 с. $560 \mathrm{c.}$

Ильина Н. И. Дороги и судьбы : автобиографич. проза. М. : Совет. писатель, 1985.

Искусство оформления книги. Работы ленинградских художников : 1917-1964 / вступит. ст. Э. Кузнецова. Л. : Художник РСФСР, 1966. 188 с.

Константин Андреевич Сомов : Письма. Дневники. Суждения современников / сост. Ю. Н. Подкопаева, А. Н. Свешникова. М. : Искусство, 1979. 624 с.

Кудесник, чародей, приспособленец...: (Интервью Ю. Демиденко с Р. Герра) // Новый мир искусства. 1998. № 2. С. 23.

Кузнецов Э. Превращения Сергея Чехонина : Зигзаги русского эстетизма // Новый мир искусства. 1998. № 2. С. 20-22.

Лейкинд О. Л., Махров К. В., Северюхин Д. Я. Художники русского зарубежья. 1917-1941 : биографич. словарь. СПб. : Нотабена, 1999. 718 с.

Лапшин В. П. Художественная жизнь Москвы и Петрограда в 1917 году. М. : Совет. художник, 1983. 496 с.

Липович И. Н. Альбом С. В. Чехонина из собрания Государственного Русского музея // Музей'9. М. : Совет. художник, 1988а. С. 152-158.

Липович И. Н. Книжная графика С. В. Чехонина // Иллюстрация. М. : Совет. художник, 1988б. 192 с.

Липович И. Н. Сатирические символы Чехонина // Творчество. 1990. № 1. C. 30-32.

Лянда Н. Ю. Агитационный фарфор С. В. Чехонина // Вопросы развития советского искусства и искусства народов СССР : тематич. сб. науч. тр. Л., 1972. C. $101-104$.

Лянда Н. Ю. Новые материалы о дореволюционном периоде творчества С. В. Чехонина // Проблемы развития русского искусства : тематич. сб. науч. тр. Л., 1974. Вып. 6. С. 71-77.

Мароши B. В. Зверинцы и зоосады в русской литературе XIX - начала XX в. : Между раем и адом // Quaestio Rossica. 2015. № 1. С. 153-173.

Милашевкий B. Вчера, позавчера : Воспоминания художника. Л. : Художник РСФСР, 1972. 497 c.

«Мир искусства»: к 100-летию выставки русских и финляндских художников 1898 года : [каталог юбилейной выставки и сборник статей] // науч. ред. В. Леняшин. СПб. ; Хельсинки : Palace Ed., 1998. 336 с.

«Мир искусства»: Объединение русских художников начала XX века / вступит. ст. В. Петрова, А. Каменского ; сост. А. Каменский. Л. : Аврора, 1991 [на англ., фр. и нем. яз.]. $332 \mathrm{c.}$

Они унесли с собой Россию... Русские художники-эмигранты во Франции. 19201970-е. : Из собрания Рене Герра : каталог выставки / авт.-сост. А. Толстой, Р. Герра. М. : Авангард, 1995. 168 с.

Петров В. Мир искусства. М. : Изобразит. искусство, 1975. 248 с.

Петровский М. С. Книги нашего детства. М. : Книга, 1986. 286 с.

Подобедова О. И. Евгений Евгеньевич Лансере. М. : Искусство, 1961. 420 с.

Пружан И. Н. Лев Самойлович Бакст. Л. : Искусство, 1975. 232 с.

Русский художественный фарфор : сборник статей о Государственном фарфоровом заводе / под ред. Э. Ф. Голлербаха, М. В. Фармаковского. Л. : Госиздат, 1924. $162 \mathrm{c}$.

Русское богатство. 1993. № 2. С. 167. 
Сергей Васильевич Чехонин. 1878-1936 : каталог выставки // авт-сост. Е. А. Иванова, И. Н. Липович. СПб. : Гос. Рус. музей, 1994.

Сергей Дягилев и русское искусство : Статьи, открытые письма, интервью. Переписка, современники о Дягилеве : в 2 т / сост., вступит ст. и коммент. И. С. Зильберштейн, В. А. Самкова. М. : Изобразит. искусство, 1982. Т. 1. 496 с.; T. 2. $576 \mathrm{c}$.

Сидоров A. A. Русская графика начала XX века : Очерки истории и теории. М. : Искусство, 1969. 252 с.

Советский фарфор: искусство Государственного фарфорового завода имени

М. В. Ломоносова / сост., текст А. К. Лансере. Л. : Художник РСФСР, 1974. 278 с.

Современная русская графика / под ред. С. Маковского ; текст Н. Радлова. Пг. :

Свободное искусство, 1917. $148 \mathrm{c.}$

Стравинский И. Ф. Статьи и материалы. М. : Совет. композитор, 1973. 526 с.

Чуковский К. Дневник : в 2 т. 1901-1929. М. : Совет. писатель, 1991-1995. Т. 1.

$1901-1929.544$ c. Т. $2.1930-1969.560$ c.

Чукоккала : Рукописный альманах Корнея Чуковского. М. : Искусство, 1979. 446 с.

Швари Е. Л. Из автобиографической прозы : Письма. Воспоминания о писателе.

М. : Книж. палата, 1991.368 с.

Швари Е. Живу беспокойно... : Из дневников. Л. : Совет. писатель, 1990. 751 с.

Эфрос A. Концы без начал : Искусство и революция // Творчество. 1990.

№ 3. C. $14-17$.

Эфрос А. Чехонин // Профили. М. : Федерация, 1930. С. 209-223.

Эфрос А., Пунин Н. С. Чехонин. М. ; Пг. : Госиздат, 1924. 113 с.

Ярустовский Б. М. Игорь Стравинский. М. : Совет. композитор, 1969. 320 с.

B. E. W. Tschechonin // Kunst. 1929. Bd. 60. Juni. S. 221-224.

Эфрос А., Пунин Н. С. Чехонин. М. ; Пг. : Госиздат, 1925.

Expositioa Serge Tchékhonine chez A. Marchak / texte N. Clouzot [catalogue] // The Studio. 1926. Vol. 91. P. 70.

\section{References}

Akimov, N. (1991). Nash avtor Evgeniy Shvarts [Our Author Evgeny Schwartz]. In Zhitieskazochnika. Evgeniy Shvarts: Iz avtobiograficheskoy prozy. Pis'ma. Vospominaniya o pisatele (pp. 227-234). Moscow, Knizhnayapalata.

Andreeva, L. V. (1978). O poslednikh godak htvorchestva S. V. Chekhonina [On S. V. Chekhonin's Final Works]. In Sovetskoe dekorativnoe iskusstvo' 76 (pp. 230248). Moscow, Sovetsky khudozhnik.

Andreeva, L. V. (1975). Sovetsky farfor: 1920-1930-e gody [Soviet Porcelain between the 1920s and 1930s]. 240 p. Moscow, Sovetsky khudozhnik.

B. E. W. (1929). Tschechonin. In Kunst, Bd. 60, Juni, pp. 221-224.

Benua, A. (1996). Vybrannye mesta iz dnevnika 1916-1918 godov [Selected Excerpts from A. Benois's Diary]. In Mir muzeya, 5, p. 52; 6, pp. 43-44.

Borev, N. (1993). Avtobiografiya "Voskresshego iz zhivykh" [An Autobiography of One Risen from the Living]. In Russkoe bogatstvo, 2, pp. 6-17.

Botsyanovsky, V. (1925). Khudozhnik dvukh revolyutsiy [The Artist of Two Revolutions]. In Byloe, I, pp. 237-258.

Boult, Dzh. E. (1990). Khudozhniki russkogo teatra: 1880-1930 [The Artists of the Russian Theatre: 1880-1930]. 112 p. Moscow, Iskusstvo.

Chukovsky, K. (1991). Dnevnik: 1901-1929 [Diary: 1901-1929]. Vol. 1. 544 p.

Moscow, Sovetsky pisatel'.

Chukovsky, K. (1995). Dnevnik: 1930-1969 [Diary: 1930-1969]. Vol. 2. 560 p.

Moscow, Sovetskypisatel'.

Chukokkala: Rukopisny al'manakh Korneya Chukovskogo [The Hand-written Almanac of Korney Chukovsky]. (1979). 446 p. Moscow, Iskusstvo.

Dan'ko, E. S. (1928). V. Chekhonin [V. Chekhonin]. In Mastera sovremennoy gravyury I grafiki (pp. 61-65). Moscow, Leningrad, Gosizdat.

Dombrovsky, A. (2010). Chekhonin: mezhdu krugom I kvadratom [Chekhonin:

Between the Circle and the Square]. In Proektor, 2 (11), pp. 40-47.

Efros, A. (1990). Kontsy bez nachal: Iskusstvo i revolyutsiya [Ends without Beginnings: Art and Revolution]. In Tvorchestvo, 3, pp. 14-17. 
Efros, A. (1930). Chekhonin [Chekhonin]. In Profili (pp. 209-223). Moscow, Federatsiya. Efros, A., \& Punin, N. S. (1924). Chekhonin [Chekhonin]. 113 p. Moscow, Petrograd, Gosizdat.

Efros, A. \& Pounine, N. (1925). Tchékhonine. Moscow, Leningrad, Editiondel'Etat.

Evseev, M. Yu. (1986). "Pochtovoe vedomstvo zakazalo nashim khudozhnikam...": $K$ istorii proektov pervykh sovetskikh pochtovykh marok ["The Post Ordered from Our Artists...": On the History of the Plans for the First Soviet Stamps]. In Panorama iskusstv'9 (pp. 272-276). Moscow, Sovetsky khudozhnik.

Expositioa Serge Tchékhonine chez A. Marchak / texte N. Clouzot [catalogue]. In The Studio. (1926). Vol. 91, p. 70.

Gankina, E. Z. (1963). Russkie khudozhniki detskoy knigi [Russian Artists of Children's Books]. 278 p. Moscow, Sovetsky khudozhnik.

Gasparov, B. M. (1992). Moy do dyr [Moy do dyr]. In Novoe literaturnoe obozrenie, 1, pp. 304-319.

Gerchuk, Yu. Ya. (1978). Iskusstvo Sergeya Chekhonina [Sergey Chekhonin's Art]. In Tvorchestvo, 2, pp. 20-23.

Gerchuk, Yu. Ya. (1989). Ornamentalist revolyutsii [The Ornamentalist of the Revolution]. In Gerchuk, Yu. Ya. Khudozhestvennye miry knigi (pp. 149-153). Moscow, Kniga.

Gerra, R. S. (1981). Chekhonin-master russkoy grafiki [Chekhonin - a Master of Russian Graphic Art]. In Russkyal'manakh (pp. 184-187). Paris.

Gollerbakh, E. S. (1922). Chekhonin [Chekhonin]. In Kazansky muzeynyy vestnik, 1.

Gollerbakh, E. (1923). Chekhoninskaya shkola farfora [Czechoslovakian School of Porcelain Art]. In Spolokhi, 15-16.

Gollerbakh, E. F. \& Farmakovsky, M. V. (Eds.). (1924). Russky khudozhestvennyy farfor: Sbornik statey o Gosudarstvennom farforovom zavode [Russian Artistic Porcelain: Articles about the State Porcelain Factory]. 162 p. Leningrad, Gosizdat.

Golynets, S. (2010). Bakst, Bilibin, Chekhonin: etapy stanovleniya I razvitiva miriskusnicheskoy grafiki [Bakst, Bilibin, Chekhonin: The Establishment and Development of the Graphic Art of Mir Iskusstva]. In S. P. Dyagilev I sovremennaya kul'tura: Materialy mezhdunarodnogo simpoziuma “XIII Dyagilevskie chteniya” (pp. 73-79). Perm, Izd-vo Ot i Do.

Golynets, S. (1997). Chekhonin Sergey Vasil'evich [Chekhonin Sergey Vasilyevich]. In Russkoe zarubezh'e: Zolotaya kniga emigratsii: Pervaya tret' XX veka: Entsiklopedichesky biografichesky slovar' (pp. 695-698). Moscow, Rosspen.

Golynets, S. V. (Ed., Comp.). (1970). Ivan Yakovlevich Bilibin: Stat'i. Pis'ma. Vospominaniya o khudozhnike [Ivan Yakovlevich Bilibin: Articles. Letters. Memoirs about the Artist]. 376 p. Leningrad, Khudozhnik RSFSR.

Golynets, S. (1994). Sergey Chekhonin: Serp I Molot I Tarakanishche [Sergey Chekhonin: The Hammer and the Sickle and the Monster Cockroach]. In Voprosy iskusstvoznaniya, 1, pp. 295-299.

Golynets, S. (1999). Serp I molot I Tarakanishche u istokov sovetskogo iskusstva [The Hammer and the Sickle and the Monster Cockroach in the Origins of Soviet Art]. In Yekaterinburgsky gumanitary: Nauchnyy al'manakh, 1, pp. 71-92.

Gomberg-Verzhbinskaya, E. P. (1960). Russkoe iskusstvo I revolyutsiya 1905 goda: Zhivopis'. Grafika [Russian Art and the 1905 Russian Revolution: Fine Art. Graphic Art].175 p. Leningrad, Izd-vo LGU.

Graficheskoe iskusstvo v SSSR: 1917-1927 [Graphic Art in the USSR]. (1927). 294 p. Leningrad, Izd-vo Leningradskoy akademii khudozhestv.

Il'ina, N. I. (1985). Dorogi i sud'by: Avtobiograficheskaya proza [Roads and Destinies: Autobiographical Prose]. 560 p. Moscow, Sovetskiy pisatel'.

Ivanchenko, A. V. (1987). Soyuz Serpa I Molota: Gosudarstvennye simvoly RSFSR [The Union of the Sickle and Hammer: RSFSR State Emblems]. 158 p. Moscow, Sovetskaya Rossiya.

Ivanova, E. A. \& Lipovich, I. N. (Comp.). (1994). Sergey Vasil'evich Chekhonin. 1878-1936: Katalog vystavki [Sergey Vasilyevich Chekhonin. 1878-1936: Exhibition Catalogue]. Sankt Petersburg.

Kudesnik, charodey, prisposoblenets... (Interv'yu Yu. Demidenko s R. Gerra) [A Miracle Worker, Enchanter, Trimmer... (Yuri Demidenko’s Interview with René Guerra)]. (1998). In Novyy mir iskusstva, 2, pp. 23.

Kuznetsov, E. (Foreword). (1966). Iskusstvo oformleniya knigi: Raboty leningradskikh khudozhnikov. 1917-1964 [The Art of Book Design: Leningrad Artists' Works]. 188 p. Leningrad, Khudozhnik RSFSR. 
Kuznetsov, E. (1998). Prevrashcheniya Sergeya Chekhonina: Zigzagi russkogo estetiz$m a$ [Sergey Chekhonin's Transformations: The Zigzags of Russian Aestheticism]. In Novyy mir iskusstva, 2, pp. 20-22.

Lansere, A. K. (1974). Sovetskiy farfor: iskusstvo Gosudarstvennogo farforovogo zavoda imeni M. V. Lomonosova [Soviet Porcelain: The Works of State Porcelain Factory n. a. M. V. Lomonosov]. 278 p. Leningrad, Khudozhnik RSFSR.

Lapshin, V. P. (1983). Khudozhestvennaya zhizn' Moskvy I Petrograda v 1917 godu [The Artistic Life of Moscow and Petrograd in 1917]. 496 p. Moscow, Sovetsky khudozhnik.

Lenyashin, V. (Ed.). (1998). "Mir iskusstva”: $k$ 100-letiyu Vystavki russkikh I finlyandskikh khudozhnikov 1898 goda: [Katalog yubileynoy vystavki I sbornik statey] ["Mir iskusstva": For the $100^{\text {th }}$ Anniversary of the Exhibition of Russian and Finnish Artists in 1898]. 336 p. Sankt Petersburg, Helsinki, Palace Ed.

Leykind, O. L., Makhrov, K. V. \& Severyukhin, D. Ya. (1999). Khudozhniki russkogo zarubezh'ya. 1917-1941: Biografichesky slovar' [Russian Émigré Artists. 1917-1941: A Biographical Dictionary]. 718 p. Sankt Petersburg, Notabena.

Lipovich, I. N. (1988). Al'bom S. V. Chekhonina iz sobraniya Gosudarstvennogo Russkogo muzeya [S. V. Chekhonin's Album from the Collection of the Russian Museum]. In Muzey'9 (pp. 152-158). Moscow, Sovetsky khudozhnik.

Lipovich, I. N. (1988). Knizhnaya grafika S. V. Chekhonina $[\mathrm{S}$. V. Chekhonin's Book Illustrations]. In Illyustratsiya. 192 p. Moscow, Sovetsky khudozhnik.

Lipovich, I. N. (1990). Satiricheskie simvoly Chekhonina [Chekhonin's Satirical Symbols]. In Tvorchestvo, 1, pp. 30-32.

Lyanda, N. Yu. (1972). Agitatsionnyy farfor S. V. Chekhonina [S. V. Chekhonin's Agitation Porcelain]. In Voprosy razvitiya sovetskogo iskusstva I iskusstva narodov SSSR: Tematichesky sbornik nauchnykh trudov (pp. 101-104). Leningrad.

Lyanda, N. Yu. (1974). Novye materialy o dorevolyutsionnom periode tvorchestva S. V. Chekhonina [New Materials about S. V. Chekhonin's Pre-revolutionary Period of Work]. In Problemy razvitiya russkogo iskusstva: Tematichesky sbornik nauchnykh trudov (Iss. 6, pp. 71-77). Leningrad.

Maroshi, V. V. (2015). Zverintsy I zoosady v russkoy literature XIX-nachala XX v.: Mezhdu raem I adom [Menageries and Zoos in the Russian Literature of the $19^{\text {th }}$ and Early $20^{\text {th }}$ Centuries: Between Heaven and Hell]. In Quaestio Rossica, 1, pp. 153-173.

Milashevky, V. (1972). Vchera, pozavchera: Vospominaniya khudozhnika [Yesterday, the Day Before Yesterday: An Artist's Recollection].497 p. Leningrad, Khudozhnik RSFSR.

Petrov, V. (1975). Mir iskusstva [Mir iskusstva]. 248 p. Moscow, Izobrazitel'noe iskusstvo.

Petrov, V. \& Kamensky, A. (Foreword, Comp.). (1991). "Mir iskusstva”: Ob"edinenie russkikh khudozhnikov nachala XX veka [ "Mir iskusstva": A Russian Artistic Group of the Early $20^{\text {th }}$ Century]. (In English, in French, in Deutsch). 332 p. Leningrad, Avrora.

Petrovsky, M. S. (1986). Knigi nashego detstva [Books of Our Childhood]. 286 p. Moscow, Kniga.

Podkopaeva, Yu. N. \& Sveshnikova, A. N. (Comp.). (1979). Konstantin Andreevich Somov: Pis'ma. Dnevniki. Suzhdeniya sovremennikov [Konstantin Andreevich Somov: Letters. Diaries. Opinions of His Contemporaries]. 624 p. Moscow, Iskusstvo.

Podobedova, O. I. (1961). Evgeniy Evgen'evich Lansere [Evgeny Evgenyevich Lansere]. 420 p. Moscow, Iskusstvo.

Pruzhan, I. N. (1975) Lev Samoylovich Bakst [Lev Samoylovich Bakst]. 232 p. Leningrad, Iskusstvo.

Radlov, N. \& Makovsky, S. (Ed.). (1917). Sovremennaya russkaya grafika [Contemporary Russian Graphic Art].148 p. Petrograd, Svobodnoe iskusstvo.

Russkoe bogatstvo [Russian Wealth]. (1993). Iss. 2, p. 167.

Shvarts, E. L. (1991). Iz avtobiograficheskoy prozy. Pis'ma. Vospominaniya o pisatele [Excerpts from Autobiographical Prose. Letters. Memoirs about the Writer]. 368 p. Moscow, Knizhnaya palata.

Shvarts, E. (1990). Zhivu bespokoyn... Iz dnevnikov [I Live Uneasily... From My Diaries]. 751 p. Leningrad, Sovetsky pisatel'.

Sidorov, A. A. (1969). Russkaya grafika nachala XX veka: Ocherki istorii I teorii [The Russian Graphic Art of the Early 20 ${ }^{\text {th }}$ Century: Essays on History and Theory]. 252 p. Moscow, Iskusstvo. 
Stravinsky, I. F. (1973). Stat'I I materialy [Articles and Materials]. 526 p. Moscow, Sovetsky kompozitor.

Tolstoy, A. \& Gerra, R. (Comp.). (1995). Oni unesli s soboy Rossiyu... Russkie khudozhniki-emigranty vo Frantsii. 1920-1970-e.: Izsobraniya Rene Gerra: Katalog vystavki [They Took Russia with Them... Russian Émigré Artists in France between the 1920s and 1970s: From René Guerra's Collection: An Exhibition Catalogue]. 168 p. Moscow, Avangard.

Yarustovsky, B. M. (1969). Igor' Stravinskiy [Igor Stravinskiy]. 320 p. Moscow, Sovetsky kompozitor.

Zil'bershteyni, I. S. \& Samkov, V. A. (Foreword, Comp.). (1982). Sergey Dyagilev I russkoe iskusstvo: Stat'i, otkrytyepis'ma, interv'yu. Perepiska, sovremenniki o Dyagileve : $v 2 t$. [Sergei Diaghilev and Russian Art: Articles, Open Letters, Interviews. Correspondence, Contemporary Memoirs]. Vol. 1, 496 p.; Vol. 2, 576 p. Moscow, Izobrazitel'noe iskusstvo.

Zolotonosov, M. (1992). Akhutokots-akhum [Akhutokots-Akhum]. In Novoe literaturnoe obozrenie, 2, pp. 262-282.

Zolotonosov, M. (1998). "Fominki" po klassitsizmu: Fantaziya na arkhitekturnye temy [A Memorial to Classicism in Fominki: Fantasias on Architectural Themes]. In Novyy mir iskusstva, 2, pp. 10-13.

The article was submitted on 04.09.2015

Translated by Anna Dergacheva 